УДК 378: 81

DOI:

Ірина Розман, кандидат педагогічних наук, доцент, доцент кафедри англійської філологї та методики викладання іноземних мов

Мукачівського державного університету

Любов Гарапко, аспірант кафедри англійської філологї та методики викладання іноземних мов Мукачівського державного університету

\title{
ДЖЕРЕЛЬНА БАЗА ДОСЛІДЖЕНЬ УКРАЇНСЬКИХ НАУКОВЦІВ ПРО ЗАРУБІЖНУ ІНШОМОВНУ ОСВІТУ
}

У статті здійснено спеціальний синтезований аналіз джерельної бази досліджень украӥнських науковиів про розвиток зарубіжної іншомовної освіти. 3'ясована відмінність у розумінні сутності двох категорійфеноменів: історіографічне джерело та автентичне першоджерело. На основі аналізу близько 80 репрезентативних студій украӥнських науковиів (монографії, дисертації, наукові статті, навчальні посібники тощо) здійснено класифікацію їхньої джерельної бази. За ї̈ основу взято такі основні критерії, як офічійний статус і походження документа, його сутнісно-змістова наповненість, інформаційна значущість тощо.

Ключові слова: педагогічна компаративістика; зарубіжна іншомовна освіта; джерело; джерельна база; документальні матеріали.

Jim. 5.

Iryna Rozman, Ph.D.(Pedagogy), Associate Professor, Associate Professor of the English Philology and Methods of Teaching Foreign Languages Department Mukachevo State University

Lyubov Harapko, Postgraduate Student of the English Philology and Methods of Teaching Foreign Languages Mukachevo State University

\section{SOURCE BASE OF UKRAINIAN SCIENTIFIC RESEARCH ABOUT FOREIGN LANGUAGE EDUCATION}

The article presents a special synthesized analysis of the source base researches of Ukrainian scientists on the development of foreign language education. The difference in the understanding of two categories-phenomena is revealed: the historiographical source and the authentic primary source.Based on the analysis of about 80 representative studios of Ukrainian scientists (monographs, dissertations, scientific articles, manuals, etc.), the classification of their source base is made. It is based on such main criteria as the official status and origin of the document, its substantive content, information significance, etc.

Seven major groups of documentary materials on the development of foreign language education have been identified and 1) legislative and normatively-legal acts about education and language policy of foreign countries (normative documents of governments and regional goverment bodies, national concepts, programs, educational development projects); 2) international documents and national organizations on language policy, cultural and educational rights of national minorities differ in status and natural activities of public organizations and formal and informative status of the document (program documents which defining development strategies); accepted resolutions of general collections, forums; resolved the leading organs, etc.) 3)educational standards and educational support for foreign language education4) materials of the periodical press; 5) statistics materials; 6) abstract and encyclopedic publications; 7) electronic resources. There have been determined the tendencies of development and the modernization of research of the Ukrainian scientists on this problem.

Keywords: pedagogical comparative studies; foreign language education; source; the source base; documentary materials.

П остановка проблеми. Джерельна база - стрижневий компонент кожного конкретного історикопедагогічного дослідження, який значною мірою визначає його структуру, змістове наповнення, формулювання теоретичних положень, узагальнень і висновків. Це актуалізує проведення спеціального джерелознавчого аналізу студій 3 проблеми зарубіжної іншомовної освіти, які, зважаючи на їхню значну кількість, тематичне розмаїття, наукову і практичну значущість, становлять окреме цікаве явище української педагогічної компаративістики.

При розв'язанні цього завдання виходимо 3 принципово важливого науково-методологічного положення щодо розрізнення і розмежування двох 
категорій-феноменів: а) історіографічне джерело, до яких відносимо монографії, дисертації, автореферати, узагальнювальні історикопедагогічні праці, наукові статті, матеріали наукових конференцій, довідникову літературу, інші результати дослідницько-аналітичної праці науковців; б) автентичне першоджерело як “джерело-факт”, “джерело-подія”, тобто документальні матеріали, що дають фактографічну або іншу інформацію, яке не має науко-теоретичних оцінок і характеристик. Ці дві групи джерел є предметом нашого розгляду.

Аналіз останніх досліджень. Для вивчення означеної проблеми важливе значення має доробок українських і зарубіжних учених у трьох основних напрямах: a) розробка науковометодологічних проблем історико-педагогічної науки і компаративістики (Н. Абашкіна, Б. Вульфсон, О. Джуринський, О. Заболотна, К. Корсак, В. Кравець, Н. Лавриченко, О. Локшина, 3. Малькова, А. Сбруєва та ін.); б) вивчення історіографічних і джерелознавчих аспектів їхньго розвитку (Л. Голубнич, Т. Завгородня, Н. Гупан, Н. Дічек, Е. Днєпров, І. Кулик, Б. Савчук, І. Стражнікова, О. Сухомлинська та ін.);в)дослідження про розвиток зарубіжної іншомовної освіти, які становлять предмет цього дослідження.

Мета статті полягає у здійсненні синтезованого аналізу джерельної бази досліджень українських учених про розвиток зарубіжної іншомовної освіти та розробці їхньої класифікації і визначенні інформативного потенціалу.

Виклад основного матеріалу. Із середини 90-х рр. ХХ ст. спостерігаємо тенденцію щодо зростання кількості студій, присвячених розвитку зарубіжної освіти, зокрема комплексу проблем, що стосуються іншомовного навчання. При цьому цілком закономірно розширюється їхня джерельна база. За основу ії аналізу взято репрезентативний науковий доробок у вигляді монографій, дисертацій, наукових статей, навчальних посібників тощо близько 80 українських науковців (Н. Абашкіна, О. Авксентьєва, Е. Анафієва, Р. Антонюк, В. Базова, В. Базуріна, Н. Бідюк, І. Білецька, І. Богданова, I. Бойчевська, Т.Боднарчук, Н. Бугасова, А. Бузовський, М. Винарчик, В. Гаманюк, О. Голотюк, Л. Гульпа, О. Дем’яненко, Л. Заблоцька, І. Задорожна, Л. Зайцева, О. Зіновата, О. Івашко, В. Калінін, В. Капустін, С. Каричковська, О. Карп’юк, О. Коваленко, М. Кокор, В. Корнієнко, Г. Крючков, О. Кузнєцова, М. Лещенко, О. Литвинов, О. Лопутько, І. Лощенова, С. Лук'янчук, О.Максименко,М.Махаєва, В.Махінов,М.Мельникова, М. Мікуляк, Т. Мийличенко, О. Мілютіна, І. Мінчак, Л. Мовчан, С. Ніколаєва, О. Огієнко, Т. Окуневич,
Л. Отрощенко, М. Палій, Л. Панасюк, І. Пасикова, В. Пашков, О. Першукова, В. Плахотник, А. Погрібний, В. Погребняк, І. Попеску, В. Редько, Л. Рись, I. Самойлюкевич, А. Сбруєва, О. Сєргєєва, О. Слоньовська, В. Смелянська, Л. Смірнова, Н. Совтис, І. Соколова, Є. Спіцин, І. Сусліна, М. Татеєва, Ю. Тельпуховська, Л. Товчигречка, I. Чернишенко, Н. Шеверун, І. Шестопалова, Ю. Шийка, І. Шкелебей, Н. Шумарова та ін.).

Їхні дослідження охоплюють широкий тематичний спектр розвитку зарубіжної іншомовної освіти, але у своїй основі циркулюють навколо трьох основних проблем: професійна мовна підготовки майбутніх педагогів і фахівців інших соціальних сфер; теорія і практика вивчення іншомовної освіти в навчальних закладах різних типів; використання зарубіжного досвіду білінгвізму в освітній сфері України тощо.

У загальному вигляді використані в дослідженнях українських учених документальні матеріали про розвиток зарубіжної іншомовної освіти можна розділити на сім основних груп: 1) законодавчі і нормативно-правові акти про освіту і мовну політику зарубіжних країн; 2) документи міжнародних і національних організацій про мовну політику, культурно-освітні права національних меншин тощо; 3) освітні стандарти та навчально-методичне забезпечення іншомовної освіти; 4) матеріали періодичної преси; 5) матеріали статистики; 6) реферативні та енциклопедичні видання; 7) електронні ресурси. У цій класифікації виходили з таких основних критеріїв, як офіційний статус і походження документа, його сутнісно-змістова наповненість, інформаційна значущість та ін.

Схарактеризуємо докладніше означені групи джерельних матеріалів.

Насамперед відзначмо, що у процесі збору наукової інформації дослідники опрацьовують фонди різних міжнародних і національних установ. Серед українських найбільш затребуваними $є$ фонди Національної бібліотеки України імені В. I. Вернадського, Державної науковопедагогічної бібліотеки НАПН України імені В. О. Сухомлинського, Державної науковотехнічної бібліотеки України, Центру інформації і документації Ради Європи в Україні, Інформаційного центру Свропейського Союзу, а також регіональних університетів та освітніх і наукових установ.

Завдяки стажуванню, грантовій підтримці, інших формам міжнародного співробітництва розширюються можливості українських науковців щодо роботи в закордонних міжнародних і національних установах країн, які стосуються 


\section{ДЖЕРЕЛЬНА БАЗА ДОСЛДЖЕНЬ УКРАЇНСЬКИХ НАУКОВЦІВ ПРОЗАРУБІЖНУ ІНШОМОВНУ ОСВІТУ}

предмета їхнього дослідження. До прикладу, вивчаючи тенденції розвитку іншомовної освіти у середніх навчальних закладах Угорської Республіки, Л. Гульпа опрацювала в Будапешті Фонди Угорського національного архіву (Magyar Levéltár), Національної бібліотеки імені І. Сечені (Országos Szécsényi Könyvtár) та бібліотеки Педагогічного факультету Наукового університету імені Лоранда Етвеша (Eӧtvös Loránd Tudományegyetem) [1]. До слова, сам факт використання фондів зарубіжних архівів доволі рідкісне явище в українській компаративістиці, тож вони становлять важливий, але допоки майже не затребуваний ресурс нарощування їхньої інформативної бази.

До першої групи документальних матеріалів відносимо нормативно-правові акти про освіту $і$ мовну політику, які чинні в Україні та в зарубіжних країнах. Це передусім офіційні національні документи, що визначають і регулюють державну освітню політику, нормативні документи урядів і органів регіональної влади, національні концепції, програми й різні проекти з розвитку освіти тощо.

При доборі таких документальних матеріалів науковці виходять із мети і завдань своїх конкретно-педагогічних досліджень. Так, досліджуючи стратегії забезпечення рівних освітніх можливостей молоді у скандинавських країнах, Л. Загоруйко опрацювала ухвалені в них антидискримінаційні законодавчі акти (2004, 2006, 2008 рр.), рішення парламентських комісій із питань освітньої політики, інші директивні документи та показала, що проблеми іншомовної освіти посідають в них значне місце. Це стимулювало їі розвиток і практичну реалізацію принципу білінгвізму [4].

Чи не найбільш широкою і складною для аналізу є друга група джерел, що стосується документів міжнародних і національних організацій. При цьому науковці здебільшого не вдаються до їхнього поділу, тож, гадаємо, він може здійснювати за двома універсальними ознаками: а) статусом і характером діяльності суспільних організацій (міжнародні, міждержавні, національні, регіональні тощо; напівдержавні, масові громадські (добровільні), професійні; гуманітарні, економічні, правові, освітні, культурологічні, наукові, благодійні); б) формальним і змістовно-інформаційним статусом документа (програмні документи, що визначають стратегії розвитку; ухвали і резолюції загальних зібрань, форумів; рішення керівних органів тощо).

Слід розуміти як змістовно-інформативні, так і нормативно-правові відмінності цієї групи джерел від попередньої. Документи ООН і ЮНЕСКО як провідних координаторів розвитку освіти у світі не мають зобов'язуючої сили для національних урядів, однак, завдяки своєму гуманітарному i моральному значенню, слугують орієнтиром для узгодження національних законодавчих актів 3 їхніми положеннями.

Офіційні документи Свропейського Союзу (ЄС) щодо стратегії розвитку освіти (резолюції, рекомендації, освітні програми Свропейської Ради (СР), Європейської Комісії (СК), Свропейського Парламенту (ЄП) тощо) зазвичай виконуються його країнами-членами та зобов'язують приведення у відповідність з їхніми нормами національного освітнього законодавства.

Досліджуючи зарубіжну іншомовну освіту, автори насамперед спираються на рамкові правові акти, що визначають базові принципи функціонування СС (Договір про утворення Європейського Союзу від 7 лютого 1992 р., Резолюція спеціального засідання СР в Лісабоні 23-24 березня 2000 р. тощо) та стратегії розвитку освіти країн-учасниць: доповіді ЄК “Якість шкільної освіти - шістнадцять індикаторів якості” (2000 р.) i “Конкретні майбутні завдання з освіти і систем навчання” (2001р.); рекомендації СП і EP “Ключові компетентності для навчання впродовж життя” (2006 р.), “Європейська рамка кваліфікацій для навчання впродовж життя” (2008 р.) та ін.

На основі аналізу цієї групи документів у науковців виробився консолідований погляд щодо взаємозумовленості освітньої і мовної політики, адже резолюції і ухвали СР, СП, СК слугують методологічною основою для розбудови національних освітніх систем, зокрема і в галузі іншомовної освіти. Концептуальне значення для вивчення цієї проблеми мають ще два документи: “Загальноєвропейські Рекомендації з мовної освіти” (2001р.), на основі яких розробляються навчальні програми, підручники, рівневі сертифікації, документи про рівень іншомовної компетенції в межах $\mathrm{CC}$; “Європейський Мовний Портфоліо”, який відображає рівень володіння кожним громадянином іноземними мовами за визнаними міжнародними критеріями. Розширенню доступу до цих матеріалів сприяють україномовні публікації, які супроводжуються науково-методичним аналізом основних положень та рекомендаціями до їх практичного застосування [див.: 2 - 3]. Важливу роль у розробці концепцій наукових досліджень відіграють рамкові проекти й ініціативи європейських інституцій "Сократ", "Еразмус Мундус" та ін.

Доволі затребуваними 3-поміж українських компаративістів, що вивчають проблеми 


\section{ДЖЕРЕЛЬНА БАЗА ДОСЛІДЖЕНЬ УКРАЇНСЬКИХ НАУКОВЦІВ ПРОЗАРУБІЖНУ ІНШОМОВНУ ОСВІТУ}

іншомовної освіти, є документальні матеріали таких організацій і установ, як Міжнародне бюро освіти ЮНЕСКО (UNESCO International Bureau of Education), Міжнародна асоціація оцінювання навчальних досягнень (International Association for the Evaluation of Educational Achievement), Міжнародний огляд навчального плану і системи оцінювання Інтернет-архіву (International Review of Curriculum and Assessment Frameworks Internet Archive), Свропейський інститут порівняльних культурних досліджень (European Institute for Comparative Cultural Research), Мережа освітніх систем і політики в Свропі (Network on Education Systems and Policies in Europe) та ін.

Документальні матеріали цих організацій можна розділити на дві умовні взаємопов'язані підгрупи. Перша стосується базових ухвал, концепцій, програм, які визначають основоположні засади іншомовної освіти в навчальних закладах різних типів та зміст, форми, методи роботи 3 різними категоріями емігрантів і національних меншин тощо. Друга група документів у вигляді звітів, рапортів, інформативних довідок, експертних оцінок тощо містить аналітичну інформацію про стан загальної й іншомовної освіти в різних країнах, інноваційні технології навчання мови, досвід їхньої реалізації тощо. Матеріали обох груп документів відображають стан і тенденції розвитку іншомовної освіти на різних територіально-регіональних рівнях: світовому, континентальному, окремих країн, їхніх частинах тощо.

Виокремлення третьої групи джерельних матеріалів, які стосуються освітніх стандартів і навчально-методичного забезпечення іншомовної освіти, зважаючи на критерії запропонованої класифікації, є дещо умовним, бо вони фігурують і серед іiі інших груп документів. Однак це дає змогу увиразнити джерела доступу до таких матеріалів та їхні структурно-змістові характеристики. Так, вивчаючи розвиток іншомовної освіти в середніх і вищих навчальних закладах Республіки Польща, українські дослідники (С. Каричковська, Л. Смірнова, Н. Шеверун та ін.) активно вивчають їхні навчальні плани і програми на основі інформації, одержаної із освітніх порталів Варшавського, Ягеллонського, Гданського, Вроцлавського, Люблінського ім. М. Склодовської-Кюрі, Сілезького, Білостоцького, інших університетів і ВНЗ країни. На цій основі зіставляються їхні базові характеристики $з$ відповідними документами України та країн СС тощо.

Зміст студій, на основі яких будуємо це дослідження, засвідчив, що матеріали періодичних видань є одним із найбільш затребуваних джерел інформації. Вони потребують окремої градації, чого фактично уникають дослідники, обмежуючись їхнім анонсуванням. Для цього можна обирати різні критерії. За змістом і джерелами походження матеріали преси поділяємо на науково-аналітичні статті, які відносимо до історіографічних джерел, та різновидові документальні матеріали, які охоплюють практично весь змістовий спектр вказаних у нашій класифікації першоджерел (від законодавчих актів до статистичних даних тощо).

За місцем походження і статусом періодичні видання поділяємо на три основні групи: міжнародні; українські; друковані в різних країнах. Складнішою є їхня градація за профілем, яку ілюструємо на прикладі найбільш затребуваних україномовних і англомовних часописів: a) загальнонаукові і різногалузеві ("Гуманітарні науки”, “Філософська думка”, “Вища освіта України", Assessment in Education, Journal of Philosophy of Education та ін.); б) загальноосвітні і педагогічні ("Педагогіка", "Педагогіка і психологія”, “Педагогічні науки”, "Рідна школа”, “Шлях освіти”, “Педагогічні науки: теорія, історія, інноваційні технологіï, Curriculum Studies, Education Journal, Educational Measurement, International Education Journal, European Educational Research Journal, Mesure et evaluation en education та ін.); в) профільні педагогічні, зокрема 3 компаративістики ("Професійна освіта: педагогіка і психологія”, “Порівняльно-педагогічні студіï”, “Порівняльна професійна педагогіка”, А Journal for English Teacher Education, Comparative Education Review, European Journal, Research in Comparative and International Education, Vocational Training Review of Educational Research та ін.); г) мовознавчі науково-теоретичні і навчальнометодичні часописи (“Іноземні мови”, “Іноземні мови в навчальних закладах", English Language Teaching Journal, Journal of Multilingual and Multicultural Development, Language and Intercultural Communication, Language Teaching and Linguistics, Language Teaching Journal, Review of English Language Teaching та ін.); г) регіональні, переважно педагогічні часописи, що видаються окремими ВНЗ (наприклад, “Вісник ХНУ” та ін.). Результати аналізу показали, що близько $70-80 \%$ україномовних матеріалів використовується саме з указаних українських часописів.

Дослідження про зарубіжну іншомовну освіту грунтуються на значному обсязі матеріалів статистики, які відображають показники ї розвитку на міжнародному, національному, регіональному рівнях; у різних типах навчальних 


\section{ДЖЕРЕЛЬНА БАЗА ДОСЛДЖЕНЬ УКРАЇНСЬКИХ НАУКОВЦІВ ПРОЗАРУБІЖНУ ІНШОМОВНУ ОСВІТУ}

закладів; щодо різних груп населення; в інших вимірах. Зважаючи на характер змістового наповнення таких документів, їх можна поділяти за джерелами походження: а) матеріали офіційних статистичних відомств - міжнародних (EUROSTAT, OECP, EURYDICE та ін.) або національних, тобто країн, що стали предметом дослідження; б) спеціалізовані збірники, які дають інформацію про стан і тенденції розвитку освіти у світовому і європейському просторі (Education for All Global Monitoring Report, Key Data on Education in Europe, Education at Glance; World Report on Education та ін.), зокрема про стан викладання мов у шкільних закладах (Key Data on Teaching Languages at School in Europe) тощо.

Варто визнати, що науковці нерідко зловживають матеріалами статистики (подають другорядні дані, дублюють їх і т. ін.). Це перевантажує зміст досліджень фактографізмом та актуалізує потребу підвищення дослідницької культури шляхом опанування спеціальними методами математичної статистики, які дають можливість оптимально формалізувати значні обсяги статистичної інформації.

Важливим видом джерельних матеріалів, що супроводжує весь науко-дослідницький процес та поглиблює розуміння базових аспектів наукової проблеми, є реферативні та енциклопедичні видання. Абстрагуючись від окремих Інтернет енциклопедій (Wikipedia, Gale Encyclopedia of Childhood and Adolescence), які подекуди містять фактографічні помилки і подають інформацію невисокого науково-теоретичного рівня, відзначаємо виявлену нами тенденцію, коли науковці дедалі менше покликаються на україномовну довідникову літературу, віддаючи перевагу авторитетним зарубіжним виданням. Серед останніх найбільшим попитом користуються Encyclopedia Britannica, Encyclopedia of Educational Research, European Education Thesaurus, The Encyclopedia of Informal Education, The International Encyclopedia of Education та ін. Також затребуваною є фахова лінгвістична література (The American Heritage Dictionary of the English Language, Collins English Dictionary, European Glossary on Education тощо).

Електронні ресурси в силу глобальної інформатизації науково-освітнього простору відіграють дедалі більшу роль у дослідницькій роботі, особливо коли йдеться про складні й динамічні зарубіжні феномени. Як випливає 3 аналізу досліджень про зарубіжну іншомовну освіту, що з'явилися на початку XXI ст., українські науковці активно використовують можливості доступу до Європейської мережі інформації і документації в галузі освіти (EURYDICE) та глобальної мережі Міжнародний огляд Інтернетархіву і Архівів навчальних програм і оцінювання (International Review of Curriculum and Assessment Frameworks Internet Archive). Значною популярністю серед них користується е-бібліотека Ebrary, яка дає змогу знайомитися 3 продукцією відомих академічних видавництв, зокрема Cambridge University Press, McGraw-Hill, Palgrave Macmillan; Routledge та ін.

Універсальне джерелознавче значення має електронна інформаційна база національних міністерств і відомств, що координують розвиток освіти і науки. Вона містить весь комплекс матеріалів у галузі освіти окремих країн: шкільні закони, урядові розпорядження, документи про освітні стандарти, освітні програми, навчальні плани, історичні матеріали, статистика навчальних закладів тощо. Найбільш змістовними і затребуваному в цьому сенсі є сайти навчальних закладів Австрії, Великобританії, Італії, Нідерландів, Німеччини, Польщі, Франції, Фінляндії, Швеції, інших європейських країн.

У процесі вивчення мовної проблеми також активно використовуються Інтернет-ресурси Міжнародної системи тестування 3 англійської мови, Національного центру мов Великобританії і Британської Ради в Україні та інших спеціалізованих інституцій.

Попри сталу тенденцію щодо розширення i урізноманітнення джерельної бази наукових досліджень про розвиток зарубіжної іншомовної освіти, слід визнати, що в багатьох випадках вона могла бути повнішою, більш вичерпною. У багатьох студіях недостатньо використовуються вузькопрофільні матеріали, які стосуються різних аспектів означеної проблеми.

Як приклад комплексного підходу до формування джерельного корпусу дослідження, відзначмо дисертацію Ю. Шийки, присвячену розвитку білінгвальної освіти в Канаді. Автор зібрала колекцію документів, які, з нашого погляду, доцільно поділити на такі основні групи: а) офіційні документи: законодавчі освітні акти Канади, постанови канадського уряду, звіти департаментів освіти провінцій і територій; б) матеріали 3 діяльності спеціалізованих організацій, зокрема таких, як Національна асоціація білінгвальної освіти, Білінгвальна освіта для Центральної Америки, Каліфорнійська асоціація білінгвальної освіти, Асоціація мультилінгвальної і мультикультурної освіти Іллінойсу, Студентська організація білінгвальної освіти та ін.; в) аналітичні матеріали і звіти різних дослідницьких органів, зокрема Королівської комісії з питань двомовності 
і двокультурності, Національного центру досліджень у галузі культурної різноманітності і вивчення другої мови та ін.; в) статистичні матеріали державних органів і громадських інституцій; г) навчальні плани іпрограми;г) матеріали педагогічної періодики International Journal of Bilingualism (“Міжнародний журнал з білінгвізму”), The Canadian Modern Language Review (“Огляд сучасної канадської мови”), Journal of Verbal Learning and Verbal Behaviour (“Журнал вербального навчання і вербальної поведінки"), Journal of Child Language (“Журнал дитячої мови"), Journal of Applied Research on Learning (“Журнал прикладних досліджень з навчання”), Studies in Second Language Acquisition ("Вивчення і набуття другої мови”) та ін. Опрацювання корпусу різновидових джерел уможливило авторці глибоко і предметно розкрити основні аспекти досліджуваної проблеми [5].

Насамкінець відзначмо виявлену нами загальну важливу тенденцію щодо трансформації характеру джерельної бази досліджень про розвиток зарубіжної іншомовної освіти. Аналіз бібліографічних матеріалів монографій i дисертацій, що з'явилися за два останніх десятиліття, засвідчує зростання питомої частки матеріалів іноземною мовою приблизно із 30 $40 \%$ до 60 - 70\% від загальної кількості використаних джерел. Причому більшу половину 3 них становлять нормативно-правові, організаційно-методичні і дидактичні матеріали загальноєвропейського і національного характеру. Поряд із цим істотно зменшилася частка виданих у Російській Федерації документів $з$ проблем розвитку зарубіжної освіти. Цьому сприяє і зростання кількість їхніх україномовних перекладів [див., напр.: 2 - 3]. Вони становлять значний інтерес 3-поміж науковців та широкої освітянської громадськості, тож робота в цьому напрямі має продовжуватися.

Отже, джерельна база підготовлених українськими науковцями досліджень про розвиток зарубіжної іншомовної освіти є доволі розмаїтою та охоплює широкий комплекс автентичних матеріалів, що відрізняються за походженням, змістом, інформативною насиченістю, іншими характеристиками. Розвиток глобальних електронних інформативних мереж значно розширює можливості доступу до різних джерел інформації, що, однак, не знімає потреби безпосередньої пошукової роботи науковця у фондах бібліотечних, освітніх, інших установ, де нагромаджені документи 3 досліджуваної проблеми. Усілякої підтримки з боку державних і громадських організацій заслуговує практика перекладу і видання у книжковому форматі документів про розвиток зарубіжної, зокрема й іншомовної, освіти у різних країнах.

\section{ЛІТЕРАТУРА}

1. Гульпа Л. Ю. Тенденція розвитку іншомовної освіти у середніх навчальних закладах Угорської Республіки: дис. канд. пед. наук: спец. 13.00.01 “Загальна педагогіка та історія педагогіки”. ІваноФранківськ, 2007. 231 с.

2. Європейське Мовне Портфоліо: метод. вид. / Уклад. О. Д. Карп’юк. Тернопіль, 2008. 112 с.

3. Загальноєвропейські рекомендації з мовної освіти : вивчення, викладання, оцінювання / Наук. ред. укр. вид. С. Ю. Ніколаєва. Київ, 2003. 273 с.

4. Загоруйко Л. О. Стратегії забезпечення рівних освітніх можливостей молоді у скандинавських країнах: дис. канд. пед. наук: спец. 13.00 .01 “Загальна педагогіка та історія педагогіки”. Суми. 2012. 223 с.

5. Шийка Ю.І. Розвиток білінгвальної освіти у Канаді / Л. О. Шийка : дис. канд. пед. наук: спец. 13.00 .01 “Загальна педагогіка та історія педагогіки”. Дрогобич, 2016. 285 с.

\section{REFERENCES}

1. Hulpa, L. Yu. (2007). Tendentsiia rozvytku inshomovnoi osvity u serednikh navchalnykh zakladakh Uhorskoi Respubliky [A progress of foreign language trend is in secondary schools in the Republic of Hungary]. Ivano-Frankivsk, 2007. 231 p. [in Ukrainian].

2.Ievropeiske Movne Portfolio (2008). [European Linguistic Portfolio]. (Ed.).O. D. Karpiuk. Ternopil, 112 p. [in Ukrainian].

3. Zahalnoievropeiski rekomendatsii $\mathrm{z}$ movnoi osvity: vyvchennia, vykladannia, otsiniuvannia (2003). [Pan-European recommendations are form language education: study, teaching, assessment]. (Ed.).S. Yu. Nikolaieva. Kyiv, 273 p. [in Ukrainian].

4. Zahoruiko, L. O. (2012). Stratehii zabezpechennia rivnykh osvitnikh mozhlyvostei molodi u skandynavskykh krainakh[Strategies for ensuring equal educational opportunities for young people in Scandinavian countries]. Candidate's thesis. 223 p. [in Ukrainian].

5. Shyika, Yu.I. (2016). Rozvytok bilinhvalnoi osvity u Kanadi [The development of bilingual education in Canada]. Candidate's thesis. Drohobych, 285 p. [in Ukrainian].

Стаття надійшла до редакції 22.10.2019 